\title{
Looking beyond official success measures: tales from the field of the complex forces shaping Luxembourg's ICT ecosystem
}

\author{
Nico Binsfeld ${ }^{1}$, Jason Whalley ${ }^{2}$, Lee Pugalis ${ }^{3}$ \\ ${ }^{1}$ Newcastle Business School Northumbria University, Newcastle, UK \\ Institut Supérieur de l'Economie, Luxembourg, Luxembourg \\ nico.binsfeld@isec.lu \\ ${ }^{2}$ Newcastle Business School Northumbria University, Newcastle, UK \\ Telecom Ecole de Management, Institut Mines \& Telecom, Evry, France \\ Jason.whalley@northumbria.ac.uk \\ ${ }^{3}$ Institute for Public Policy and Governance, University of Technology, Sydney \\ Leeds Business School, Leeds Beckett University, Leeds, UK \\ Lee.pugalis@uts . edu . au
}

\begin{abstract}
Information and communication technologies (ICT) are increasingly becoming an important component of economic development. Luxembourg's ICT sector is usually characterized as performing admirably - it is often at the top-end of different indices and international league tables. Nevertheless, headline statistics and high-level assessments often disguise the complexities of dynamic relations. Ecosystems are one way of understanding complex interactions and relationships. It is in this respect that this paper deploys the concept of ecosystems to investigate Luxembourg's ICT sector. The layered ecosystem model, devised by Martin Fransman, was utilized to map key actors that comprise Luxembourg's ICT ecosystem, following which a program of unstructured interviews were conducted. This empirical material, combined with documentary analysis, provides the basis for an analysis of the interrelated elements that are shaping the development of Luxembourg's ICT ecosystem. The study has identified the main forces that affect the ICT ecosystem and concluded that Luxembourg's strengths are related to its well-developed ICT infrastructures such as international fiber and national ultra-high broadband connectivity and high quality datacenters and its political vision for ICT that has led to a supportive policy environment. Its main weaknesses are related to an inappropriate educational system in which technical and scientific training is less developed, missing e-skills such as coding, application development, technical IT know-how as well a non-entrepreneurial mind-set and a risk averse culture. The paper highlights the importance of the different socio-economic, political, strategic and technological forces that shape the ICT ecosystem of a small country in order to provide a comprehensive basis for its policy makers. An empirical focus on a small country helps to redress the research imbalance, whereby small countries are often overlooked by scholars. Nevertheless, we contend that such "smallness" engenders a unique opportunity for research engagement with a majority of primary actors in ecosystems, which might be unfeasible in larger countries.
\end{abstract}

Keywords. ICT ecosystems, Luxembourg, qualitative analysis. 


\section{Introduction}

Luxembourg has one of the most developed telecommunications infrastructures within the European Union (European Commission, 2013a). Broadband and Next Generation Networks (NGN) are available to $100 \%$ of the population. The latest mobile networks technologies are present almost everywhere and the country operates about $20 \%$ of the world's high resilience datacenter capacity (Luxembourg for Business, 2013). According to the Ookla netindex ${ }^{1}$, in 2015 , Luxembourg was positioned 9th out 113 countries with mobile download speed of $23 \mathrm{Mbits} / \mathrm{s}$, and $19^{\text {th }}$ out of 202 countries with about $40 \mathrm{Mbits} / \mathrm{s}$ download speed in fixed networks. Information technologies and ecommerce are seen as growth areas for Luxembourg (PWC, 2011). ICT technologies are widely used by households and businesses and about 17.000 people work directly in ICT and many more in the related financial industry. Over the last 15 years, governments have supported the development of the ICT sector as a policy maker, as a regulator but also as ICT service provider as the Government is a $100 \%$ owner of two telecommunications operators and has invested directly or indirectly in many ICT related activities (Binsfeld, Whalley, \& Pugalis, 2013, 2015).

All of these activities have helped to create a dynamic ICT ecosystem (Rafique, Yuan, Tareen, Saeed, \& Hafeez, 2012). In addition, Luxembourg has improved in the last 15 years its relative ratings in international indices, such as, for example, the networked readiness index published annually by the World Economic Forum (World Economic Forum, Dutta, Geiger, \& Lanvin, 2015) in which Luxembourg is now placed among the top 10 most "network ready" countries in the world. Nevertheless, Luxembourg's ICT ecosystem also exhibits some frailties not always captured or transparent in international league tables.

This paper deploys a layered ecosystem model approach as proposed by Fransman (2010) as a means to identify the main actors in Luxembourg's ICT ecosystem. By applying this model, the authors aim to map the different actors in the ICT sector and analyse the relationships between the actors within the ecosystem in order to better understand how the ICT ecosystem in a small country like Luxembourg has developed over the last 15 years and more generally what are the internal and external factors that have helped to shape it over this period in time. These factors have been identified by direct interactions through extensive unstructured interviews with over 50 relevant stakeholders.

With this study, we intend to make both a contribution to better understanding the forces that shape ICT ecosystems in small countries as such countries are widely overlooked in literature and to provide an illustration of how the Fransman model may be used in practical terms. Luxembourg proves to be of particular interest for academic research and for policy making (in terms of implications) because it is a small but very open economy which is one of the most successful in the world. Luxembourg is located very centrally in Europe, is one of the founding members of the EU and is often cited in the top league international rankings. Furthermore, it can be compared to a region of larger countries and it may therefore provide some useful insight for small and open economies with similar features e.g. Singapore. In the other hand, Luxembourg does

${ }^{1}$ See http://explorer.netindex.com/maps?country=Luxembourg accessed 15.5.2015 - discontinued since 
present some interesting peculiarities such as for example a very heavy reliance of the services sector.

The remainder of the paper is structured as follows. Section 2 presents different approaches to analyse an ICT economy and introduces the Fransman ecosystem model. Section 3 provides a brief overview of the ICT ecosystem and presents some of its major developments over the last 15 years. Section 4 argues the case to develop a better understanding of the situation by conducting a qualitative exploratory analysis and presents the methodology used. Section 5 presents the outcomes of this analysis and the final section discusses this outcome and draws some conclusions.

\section{From Value Chains to Ecosystems}

This paper builds on the definition of the ICT sector and the underlying classification suggested by OECD (2011) for "measuring the information society". This definition of ICT includes IT goods and services, information content as well as telecommunications goods and services including manufacturing and production of these.

There is a wide range of models available to make sense of the structure of the ICT industry. Many of these apply or develop the Porter's value chain to the ICT environment or parts of it (Maitland et al., 2002) or have extended this model to a socalled value net (Li \& Whalley, 2002, Peppard \& Rylander, 2006, Rafique et al., 2012). This idea which has also been taken up and developed further by, for example, Hallikas et al. (2008) or Oestreicher et al (2012). Similarly, Porter's model about competitive forces (Porter, 1990) has been adapted to the ICT environment (Karagiannopoulos, Georgopoulos, \& Nikolopoulos, 2005). Along the same lines, Briglauer (2004) has developed a generic reference model in order to assess competition in different communications markets focusing on a regulatory viewpoint. Additional work has been done in characterizing the ICT Ecosystem as a network (Garcia \& Vicente, 2012), as well as looking into how such networks are built and maintained (Partanen \& Möller, 2011).

These models are essentially linear ones, but today's business environment is complex and dynamic and presents multiple relationships where companies are interacting to deliver their products and services. As a consequence, the ICT sector is increasingly characterized as a socio-technological (eco)system facing asymmetric and delayed feedback structures, which lead to turbulent changes (instability/existence of multiple equilibria) and high uncertainty.

Koslowski, Longstaff, Vidal \& Grob (2012) see the ICT sector as an ecosystem of many heterogeneous organizations that are woven into a web of links and respond interactively to forces in the environments. Understanding the dynamics of one domain in isolation from the other is impossible, and demands both a systemic and evolutionary view to be adopted. According to Kim, Lee, \& Han (2010) an ecosystem can be defined as an economic community involving many companies working together to gain comparative advantages as a result of their symbiotic relationships. They also argued that ecosystems permit companies to create new values that no company could achieve alone. Likewise, they identified symbiotic relationships that can provide some benefits for related parties such as consumers and partners. A recent discussion about using the 
ecosystems model to analyze the ICT sector is provided in Basole, Park, \& Barnett (2015).

Hence, it is important to examine ICT ecosystems in order to understand the coevolution between technological and economic as well as regulatory forces and developments and to provide a comprehensive basis for policy makers, For the purpose of understanding the structure of the ICT ecosystem in Luxembourg, it is suggested here to use a layer model described by Martin Fransman (Fransman, 2001, 2002a, 2002b, 2004, 2006, 2014). This model allows a clear identification of the different categories of actors within the system as well as the "interfaces" and relationships between those actors and thus provides a simple yet effective way to gain a good understanding of the different types of actors, their respective roles and importance to the sector as well the interrelations between them (see figure 1).

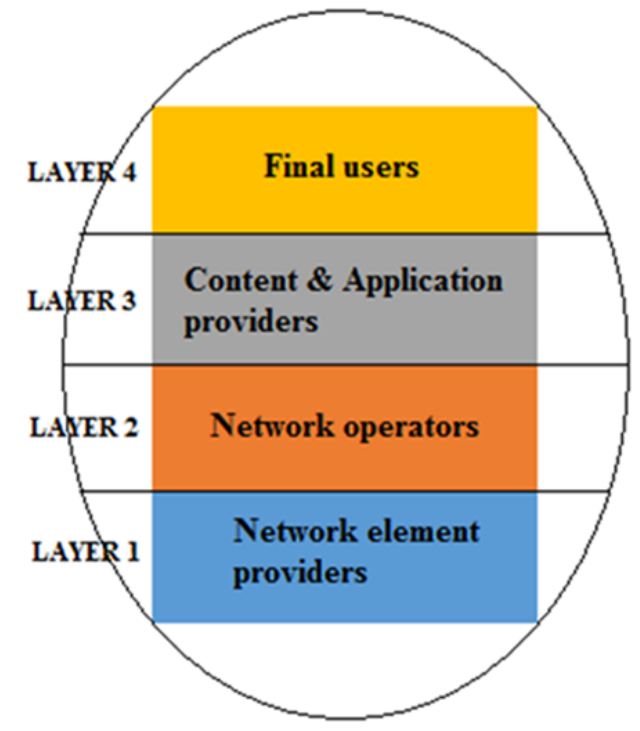

Fig. 1. The four-layer model

Fransman deliberately used the term ecosystem to stress the importance of the links between the various ICT actors. When looking at the supply side of the ICT ecosystem, four types of actors can be distinguished:

Layer I: Network element providers (e.g. Cisco, Samsung, Alcatel-Lucent, Ericsson, Nokia Networks)

Layer II: Network operators (fixed and mobile) (e.g. BT, Deutsche Telekom, Vodafone)

Layer III: $\quad$ Content \& application providers (e.g. Google, Apple, YouTube)

Layer IV: $\quad$ Final consumers

In the "new ICT ecosystem" (i.e., post-internet), users are gaining a presence on the supply side of the system by co-creating with suppliers. In contrast to the so-called "old ICT ecosystem" (i.e. pre-internet), which could be described as a closed innovation system with the most important links being between network operators and network 
suppliers (Layers I and II), the new ICT ecosystem is more open, more dynamic and more complex. In recent years, the focus has shifted to the interaction between platform, content and application providers (Layer III) and the ecosystem has become more dynamic with the relationships between the different actors and the environment also becoming more complicated.

Acknowledging these developments, Fransman (Fransman 2007, 2010, 2011), in more recent works, has focused on the role of the dynamic, or as he calls them "symbiotic", relationships between the different layers and their role for innovation (Fransman, 2014). These relationships can be described as multi-dimensional representing financial and material flows as well as information and input flows into the innovation processes within the ecosystem (see figure 2).

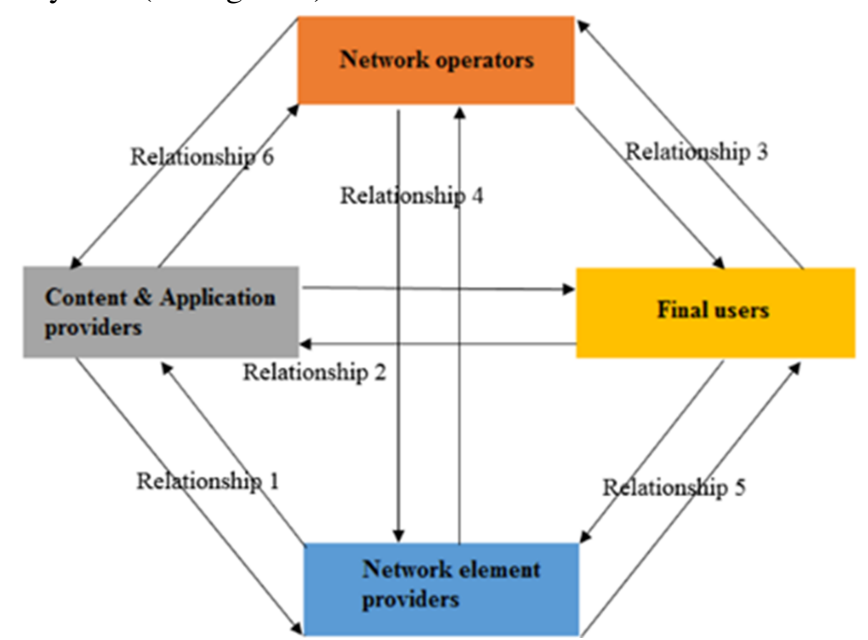

Fig. 2. Symbiotic relationships with the four-layer model

The Fransman model is not used very often by researchers in the field. Yet it is relatively simple and straightforward to apply as it builds on an ISO standardized layer model $^{2}$ which is largely used by IT engineers to explain interworking of computer and telecommunications networks. As such it provides a well-documented way of identifying the different actors and their activities which can easily be shared amongst ICT professionals as it is built on a common understanding. Furthermore, it allows to describe and identify the links and relationships between the different layers.

An example of how this model can be used to understand the interactions between different actors is provided by, for example, Arlandis \& Ciriani (2010). It also includes a detailed database of players in the different layers but takes a high level view by looking at different economic cluster such as the EU, the US and Asia. Another application of the Fransman model can be found in Veugelers (2012). Here the model is used to understand why Europe's ICT companies are lagging behind the US with regards to the "leading platform providers who are capturing most of the value in the ICT ecosystem". It is argued that a very fragmented EU market, lack of entrepreneurial mind-set, as well as lack of risk capital are the main stumbling points to the

\footnotetext{
${ }^{2}$ https://www.iso.org/standard/16011.html accessed 8.4.2017
} 
development of the ecosystem.

\section{A brief introduction into Luxembourg's ICT ecosystem}

There is an ongoing debate about what actually constitutes a small country and a summary of this discussion can be found, for example, in Roolaht (2012). Often indicators like size, population or GDP are applied. According to all of these indicators Luxembourg would actually constitute a very or even extremely small country and indeed it is one of the smallest within the EU with a land area of only $2,586 \mathrm{~km} 2$ and a population of 524,900 inhabitants (STATEC, 2013). When it comes to GDP/capita however, Luxembourg is one of the richest countries in the world (Thelen, 2012).

Following the OECD definition of ICT mentioned above, 7\% of Luxembourg's Gross Value added is generated within the sector. This share is considerably above the EU27 average which is around $4.6 \%$ of the total GVA and is the highest among EU member states (European Commission, 2013b). The country has not only a high proportion of highly skilled workers, but has also one of the highest shares of ICTusing occupations among OECD countries. The Luxembourg labour market has one of the largest shares of knowledge-intensive activities ${ }^{3}$ in Europe, with $56 \%$ of all the jobs in 2011 falling into this category (Service des Médias et des Communications, 2013). With regard to ICT infrastructure and connectivity (Fransman's layers 1 and 2) Luxembourg has invested a considerable amount to build and efficiently operate multiple state-of-the-art high capacity fibre networks (see figure 3 ). This is to ensure national and international connectivity and connecting Luxembourg to major hubs in Europe (Service des Médias et des Communications, 2013).

By 2009 100\% of Luxembourg's population was covered with 3G mobile networks, whereas in $201264 \%$ of the population were covered by the $4 \mathrm{G}$ network. Similar considerations apply to broadband connectivity and will be further developed, as, in its national strategy for very high-speed networks, issued in April 2010 (SMC, 2010a), the Government intends to increase the speeds of the existing networks, and provide, in the medium term, access to optical fibre in the entire territory. It is the Government's intention to transform Luxembourg into the first "fibred" country of the EU, if not in the world. Luxembourg has also grown into the premium location for data centre parks in Europe, with more than 19 data centres are operational (SMC, 2010b).

The 2015 STATEC bulletin on ICT in households and among individuals in 2014 (Bodson \& Frising, 2015), highlights the recent expansion of social networks and cloud activities, especially among young people. In 2014, 60\% of residents aged 16 to 74 participated in social networks, of which Facebook was the most popular as $57 \%$ of residents were active.

The Luxembourgish government has recognized the important role that ICT plays in national economic development. Luxembourg has, in recent years, experienced a major advancement with the accelerated development of the country's innovative technology companies, whether in the media sector, e-commerce, digital content, cloud computing,

\footnotetext{
${ }^{3}$ An activity is defined as being knowledge-intensive if the tertiary-educated persons employed represent more than $33 \%$ of the total employment in that activity (European Commission, 2013c)
} 
big data or electronic payments (Kitchell, 2010).

The ICT sector has also become an economic player in its own right, attracting substantial foreign direct investments (see overview of main actors in figure 5) and is not merely limited to its function as a services provider to other economic sectors. In both ways, as an economic sector by itself and as a vector of competitiveness for all other socio-economic sectors, the ICT sector will play an important part in the modernisation, performance, competitiveness and efficiency of the country.

In order to strengthen and consolidate the country's position in the field of ICT and to transform its ICT sector into a 'high tech' centre of excellence, the Luxembourg government, in conjunction with ecosystem stakeholders, has recently presented a new digital strategy called "Digital Lëtzebuerg" (Bettel, 2014). This programme encompasses subjects as diverse as the computerization of government services and the development of new niche markets for new markets (big data, health technologies, innovation in services to the financial sector ("FinTech") as well as virtual currencies. The government accepts this strategy and has consistently sought to implement it across all its relevant policy areas (Gouvernment du Luxembourg, 2014b).

\section{$4 \quad$ Methodology}

Whilst all of the aforementioned tends to show that the ICT ecosystem in Luxembourg has developed very well over the course of the last 15 years, it is it not clear what have been the main reasons for this relative success and whether this evolution will continue in the future. Therefore, we have applied the Fransman model in order to explore the ICT ecosystem and to identify the different forces and relationships at hand.

In a first step, the main categories of actors have been identified (see table 1) in the different layers as well as the institutions that shape and influence the relationship between the different layers using a focus group of 9 experts. The outcome of this work resulted in a summary overview of the ICT sector in Luxembourg. This model was then discussed with different stakeholders and further developed by the lead author in an interactive and iterative manner which led to the model that is presented in figure 3 (below).

Applying Fransman to this model and focusing on the above mentioned "symbiotic relationships" within the ecosystem, it is possible to identify actors at the governmental and political level that shape the regulatory and policy environment for ICT within the framework of the regulatory packages set by EU (European Commission, 2014a). Similarly, the model also allowed us to identify the different state-owned agencies and institutions that provide support to the ICT sector in terms of public funding, awareness raising and training (upper box in figure 3 ).

The next level of actors concerns regulation in the broadest sense, including the National Regulatory Authority, the Competition Authority, the National Standards Agency, the Data Protection Commission as well as regulatory authorities for the financial sectors (right box in figure 3). The ICT ecosystem is also supported by R\&D activities and organizations such as University of Luxembourg, public research centers but also venture capitalists and incubators (lower box).

Looking closer into the ecosystem itself, it is possible to identify ICT enablers that 
provide the underlying infrastructures, these include network element providers and network operators corresponding to the layers 1 and 2 of Fransman's model. Building on this, one can find the ICT service enablers that would fit within Fransman's third layer and the customers or users of ICT, of which some have been identified in the diagram above, correspond to Fransman's fourth layer. They include most of the actors in Luxembourg's well developed financial sector (KPMG, 2013). Finally, we can also identify several institutions or organizations, private and public, that are active in promoting the sector both nationally and internationally.

Building on the figure below, we have chosen to conduct a qualitative exploratory analysis (Cresswell, 2014; Easterby-Smith, Thorpe, \& Jackson, 2012) using extensive unstructured and face-to-face interviews (Schultze \& Avital, 2011) with a representative subset of the major stakeholders within the ICT ecosystem as identified through applying Fransman's model. The objective was to study the forces that shape the ICT ecosystem and to understand the interactions between the different layers and actors (symbiotic relationships).

A two stage approach was adopted, using the above mentioned focus group consisting of major industry and institutional players in order to establish an initial template through a SWOT analysis (Anderson, 2010; King, 1998). This SWOT analysis was then used to design open-ended questions to start the interviews and to assist in the later coding process of the outcome of these.

Using a qualitative approach has some limitations in terms of drawing generally applicable conclusion as discussed for example in Lincoln (1995) or Yin (2009). However, because of the small size of Luxembourg, it has been possible to interview a very wide and therefore representative set of stakeholders.

\subsection{Identification of relevant actors}

When identifying the different actors, the following criteria have been applied: size and relevance of actor, number of employees, specialization, access to key stakeholders, nationality (local or international), start-up or established actor, years of presence in Luxembourg, public or private ownership (full list in table 1 below).

Care was also given to take into the structure of ICT ecosystem which is presented in greater detail in for example Krylova (2015, p 41). She claims that "the majority of companies in the ICT sector are small (less than 50 employees), whereas the number of big companies contribute to less than $3 \%$ of market share". It was also considered that the number of actors in layer 2 and 3 is far higher than in layer 1.

\subsection{Data collection and analysis}

The recordings of the interviews, which usually lasted around 1 hour, were then imported into NVIVO, a computer aided qualitative data analysis software, to be processed (Bazeley \& Jackson, 2007; Beekhuyzen, 2010; Neill, 2013; Welsh, 2002; Wong, Medicine, \& Lumpur, 2008). As NVIVO allows the coding of the data directly in either text, pdf, audio or video files, it was decided to code straight on the audio content, transcribing and translating the main ideas and topics into text as well. Due to the multilingual workforce of Luxembourg, interviews have been conducted in four languages - Luxembourgish, French, German and English - and were partially 
translated. An advantage of NVIVO is that is allows almost instant access to any of the underlying data so that everything that has been said can be traced back directly from coded outcomes.

Coding started with the initial template from the aforementioned SWOT analysis but evolved over time. If and when a new topic emerged a new theme (code) was added in NVIVO. Interviews have been conducted until no further new codes or topics arose. Translation, partial transcription and coding took about 4 hours per interview. The use of NVIVO gives a lot of facilities, for example it allows immediate display all the codes per interviewee, it allow basic statistical analysis for example on frequency of codes, time spent on a specific message, how often a certain code or indeed expression has been used. It also allows for a graphical representation of interviews, the topics covered as well as the relationships between codes.

On the other hand, understanding and setting up the tool can be cumbersome, the raw data generate large files that are difficult to handle, the coding takes a lot of time and is necessarily somewhat subjective. As a consequence, based on some samples, coding verification has been undertaken. The tool, however, also has an "autocoding" function that could unfortunately not be used because of the respondents' use of different languages.

Table 1. Companies and institutions interviewed

\begin{tabular}{|c|c|c|}
\hline Fransman's layer & Interviewed Organizations and Institutions & Individuals \\
\hline $\begin{array}{l}\text { I - network } \\
\text { element } \\
\text { providers }\end{array}$ & Alcatel-Lucent, Cisco, HP, Unify & 4 \\
\hline $\begin{array}{l}\text { II - network } \\
\text { operators }\end{array}$ & $\begin{array}{l}\text { Broadcasting Center Europe, British Telecom, } \\
\text { Cegecom/Artelis (2), Eltrona (2), Fédération des } \\
\text { Opérateurs Alternatifs Luxembourg, HotCity, Join } \\
\text { Wireless, Post (2), Société Européenne des } \\
\text { Satellites,Telecom Luxembourg }\end{array}$ & 13 \\
\hline $\begin{array}{l}\text { III - content and } \\
\text { application } \\
\text { providers }\end{array}$ & $\begin{array}{l}\text { Association des professionels du secteur financier, } \\
\text { Association des professionels du secteur de } \\
\text { l'information, CTTL, Data4, Datacentre Luxembourg, } \\
\text { Ebrc, Itrust, Luxconnect (3), Luxcloud, Netcore, } \\
\text { Systemat, Telindus (2) }\end{array}$ & 15 \\
\hline IV - consumers & $\begin{array}{l}\text { Appolo Strategies, Association des Banques et } \\
\text { Banquiers, Exxus (2), Gartner, Ikano, Fédération des } \\
\text { Artisants, Luxembourg Business Federation, } \\
\text { ProNewTech, PwC }\end{array}$ & 10 \\
\hline $\begin{array}{l}\text { Outside } \\
\text { influencers - } \\
\text { finance, } \\
\text { regulation, } \\
\text { standardization }\end{array}$ & $\begin{array}{l}\text { Interdisciplinary Centre for Security Networking and } \\
\text { Trust (2), Institut Luxembourgeois de Regulation, } \\
\text { Luxinnovation, Luxembourg Institute of Technology, } \\
\text { Ministère de l'Economie, Moskito, Service des Médias } \\
\text { et des Communications }\end{array}$ & 8 \\
\hline
\end{tabular}




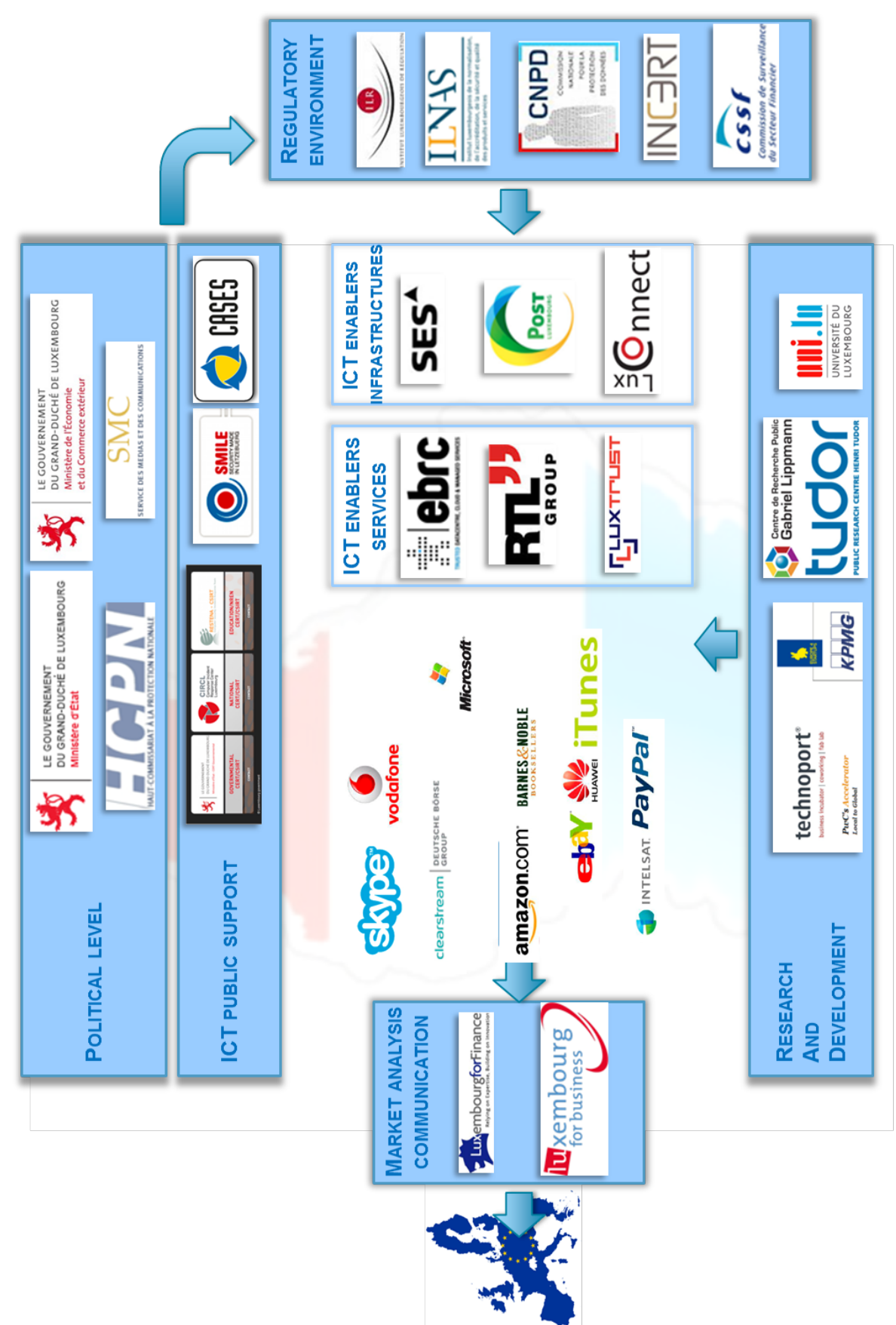

Fig. 3. Luxembourg's ICT Ecosystem (with a subset of major players) 5. Main forces shaping the Ecosystem 


\section{$5 \quad$ Main forces shaping the Ecosystem}

The following section presents the outcome of the interviews with the different stakeholders identified in table 1 . In a first analysis, the different issues mentioned were simply counted and the diagrams below show how often a given topic was mentioned. It is assumed that the frequency at which a certain topic was mentioned acts as a fair indicator for the relevance or importance of the issue. In addition, quotes have been extracted from the data and are also presented below in order to highlight and illustrate the importance of some of the major issues identified. A large majority of interviewees suggested that to make a difference between factors that Luxembourg and the actors in the ecosystem might have some control over (endogenous factors) and those that were "outside" of the ecosystem and driven mainly by the wider EU regulatory and the geopolitical competitive environment (exogenous factors). This structure is followed below.

\subsection{Exogenous Factors}

As shown in table 2 below, the interviewees identified primarily EU regulations as well as international competition as the major two external factors affecting the development of the local ecosystem.

Table 2. Examples of exogenous factors

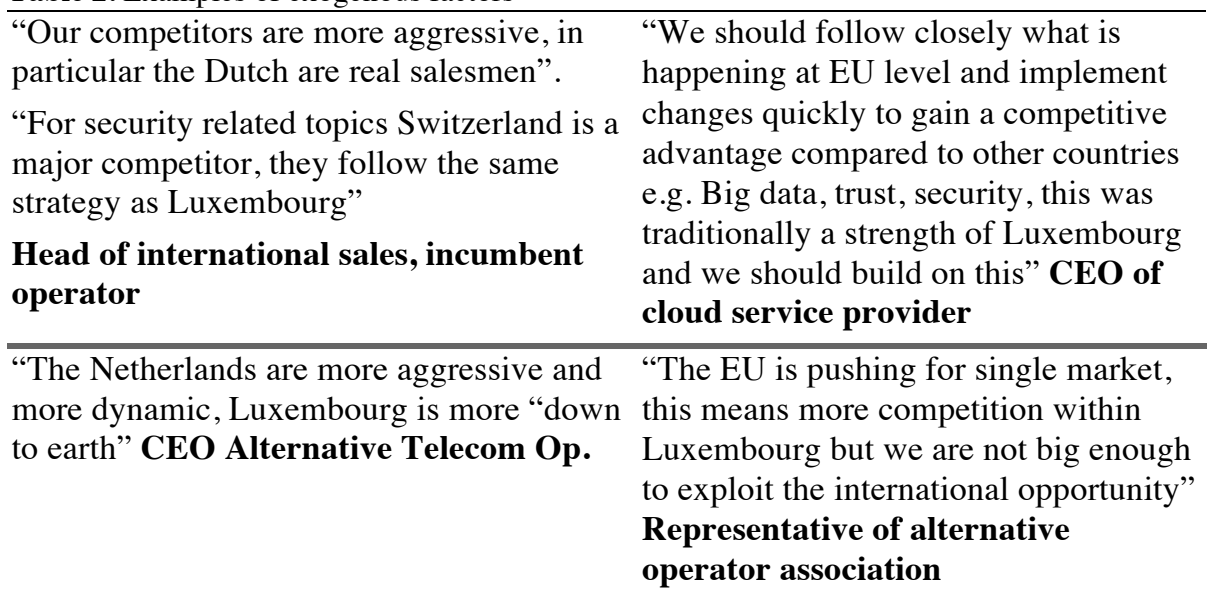

\begin{tabular}{ll}
\hline $\begin{array}{l}\text { "Almost all major European Cities are } \\
\text { competing with Luxembourg" Member of } \\
\text { Management board of bankers } \\
\text { association }\end{array}$ & $\begin{array}{l}\text { "Does Europe not have a general } \\
\text { problem here - what is still left for us? " } \\
\text { CEO of small consulting company }\end{array}$ \\
$\begin{array}{l}\text { "The question is not what should the } \\
\text { government do, but what are they still } \\
\text { allowed to do" in terms of industrial policy } \\
\text { "Luxembourg needs to do more lobbying at } \\
\begin{array}{l}\text { different levels in Brussels" } \\
\text { Representative of Business Federation }\end{array}\end{array}$ & $\begin{array}{l}\text { customers, but this money has not been } \\
\text { delecom IT sector" CEO alternative } \\
\text { telecom operator }\end{array}$ \\
\hline
\end{tabular}




\begin{tabular}{ll}
\hline "EC is putting pressure on Luxembourg & "EU regulations might limit what \\
because of IP, but there are countries that & Luxembourg can do in the future \\
do provide more tax advantages" Director & $\ldots$. even PSF might not be allowed. Why \\
at one of the "big 4" consultants & do we not push it on the EU level?" \\
& Country director global telecom \\
& equipment provider
\end{tabular}

"The whole competitiveness issue being

discussed in Europe is really

disadvantageous to small countries"

Representative of Luxembourg's

university

The influence of EU regulations. A large majority of the stakeholders are well aware that the Luxembourgish ICT ecosystem is heavily influenced and evolves within the framework of the different EU regulatory packages (see, for example, European Commission, 1987, or European Commission, 2013b). These programs that have been put in place mainly in order to stimulate competition and the move towards a digital single market (European Commission, 2010).

This topic was mentioned on over 50 occasions. It was felt that often these EU regulations are not working in favor of the ICT ecosystems of a small country like Luxembourg and the pressure towards a single EU wide market favors large or indeed global players. In this context, the discussion about reducing or abolishing roaming charges for mobile communications within the EU was mentioned on 12 occasions and is widely reported in the press, see, for example, De Fooz (2014a) or Henry (2014b) The fact that there exist many restrictions with regards to access to on-line content and geo-blocking is largely applied by major content owners was also mentioned especially by stakeholders involved with TV offers (CATV or IPTV). This prevents Luxembourgish consumers from accessing such content legally (Boston Consultancy Group, 2013).

On the other hand, several stakeholders and, in particular, those more closely linked to the financial sector, mentioned the effect of the different VAT regimes on electronic commerce. This has had, so far, a positive influence on the development of the industry (PWC, 2011). However, these stakeholders were also aware that this effect is currently about to disappear in line with EU rules (Post Telecom, 2014). 


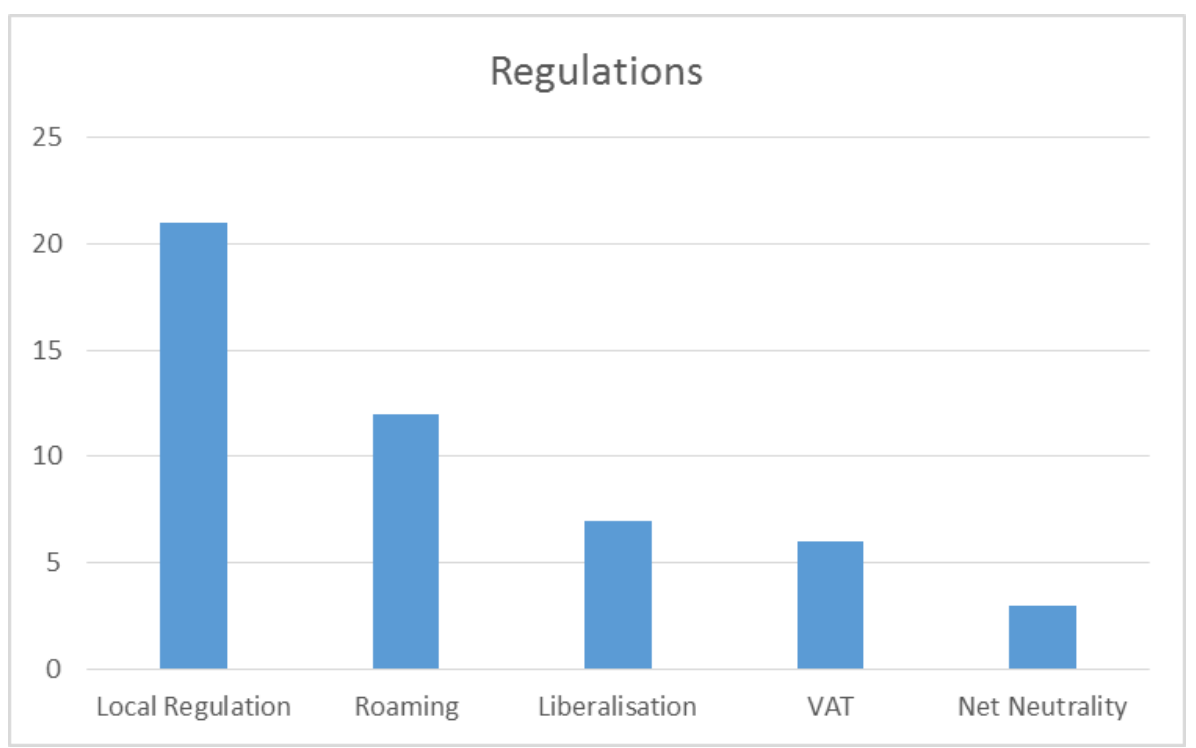

Fig. 4. Number of citations of different external regulatory/policy measures

Over 20 stakeholders identified issues related to the local implementation of the EU regulations and, amongst other things, it was felt that the national regulatory authority did not actively enough intervene in the market and did not have the necessary resources. This issue is also widely reported in the local press (Dard, 2013; Gaudron, 2011; ILR, 2013a; Le Jeudi, 2015; Poujol, 2013, 2014a) and is of particular importance to the telecommunications operators in Fransman's layer 3.

Growing international competition. In addition, international competition from different EU member states, both to attract ICT activities and on the export level, were also identified by about 20 interviewees and were said to be of growing importance. In this context, the main competitors identified were the Netherlands, Ireland as well as Luxembourg's immediate geographically neighboring countries (see figure 5 below). It was felt that competition was generally becoming more intense and that recent events around "Luxleaks" (Paperjam, 2014b; Raizer, 2014b), as well as Luxembourg's image as a "tax heaven", were negatively affecting Luxembourg's position (Guardian, 2014). It also becomes increasingly difficult to identify and communicate Luxembourg's unique selling points, with some actors commenting that a new marketing and communication strategy might be urgently needed (Bervard, 2015; Fondation Idea, 2014; Gouvernement du Luxembourg, 2014) and that the current promotion efforts needed to be better coordinated.

Overall, participants felt that both of these sets of external factors had a major influence on the ecosystem and suggested that Luxembourg, due to its small size, might be more vulnerable or exposed to the these forces that the Fransman model gives less emphasis to, as it focuses more on endogenous factors and the relationships internal to the ecosystem. 


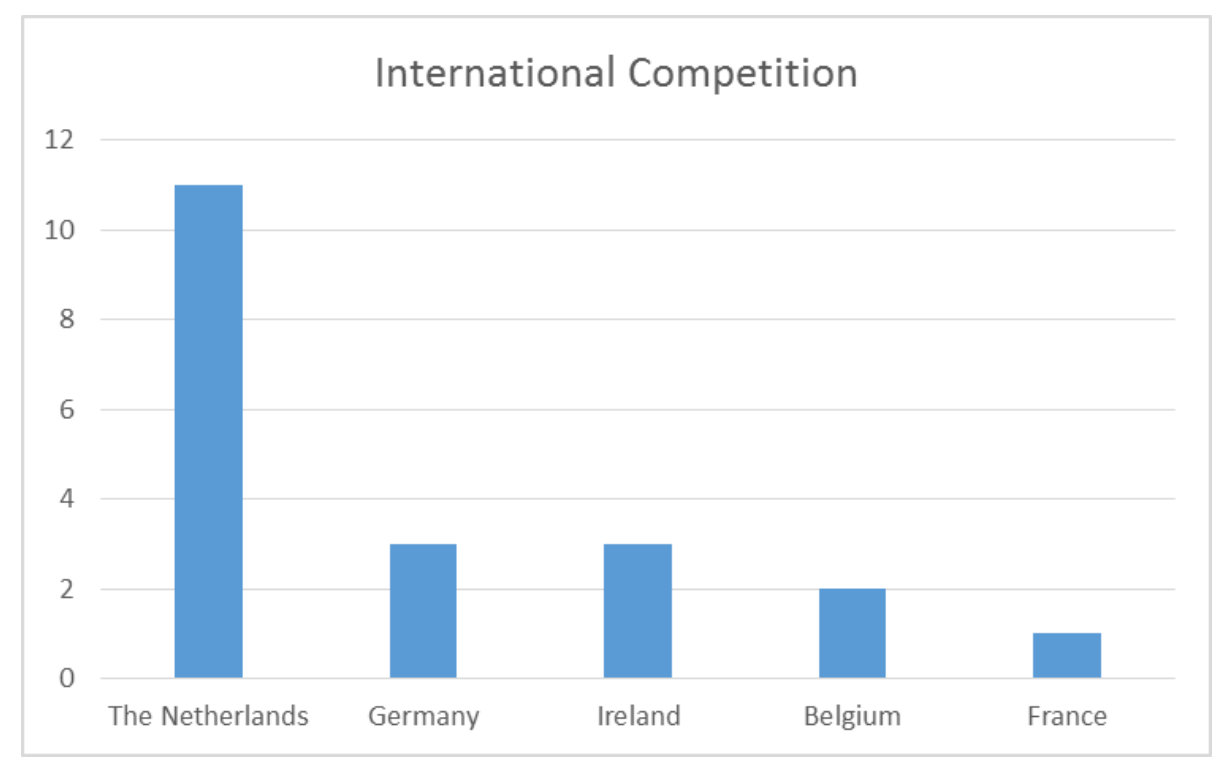

Fig. 5. International competition according to different countries

\subsection{Endogenous Factors}

Figure 6 below shows the endogenous factors that were mentioned by the different stakeholders as well as their frequency. It can be seen that these issues were mentioned far more often than the exogenous factors and the list of endogenous factors is much longer. It will, therefore, in the context of this study, not be possible to address them all in depth. Instead the objective of this paper, is to provide a broad overview and thus the following discussion will be structured by order of the importance expressed as measured by the number of times a certain topic was mentioned. 


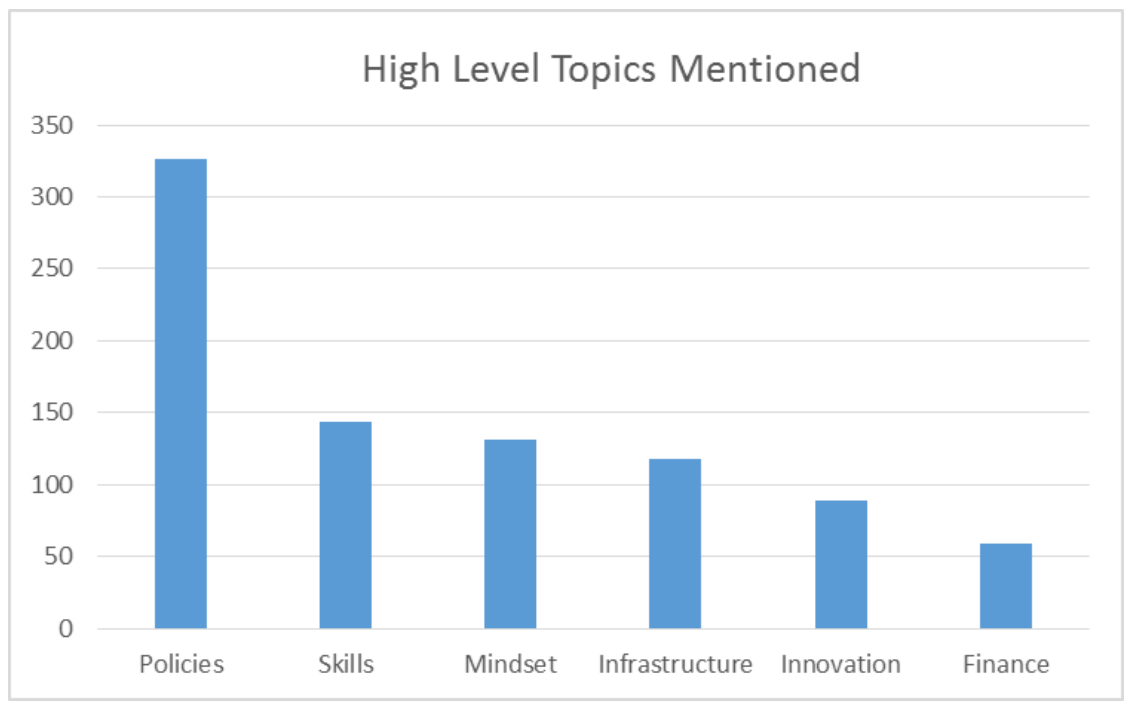

Figure 6 - Most important endogenous forces by number of mentions

Government Policies. A wide range of different policy initiatives have been identified and commented on as this subject was mentioned over 300 times. Examples of some of the main messages are presented in table 3 below.

There was, however, a large and general agreement that successive governments had taken ICT seriously and developed, as expressed by the World Economic Forum (World Economic Forum et al., 2015), a "vision for ICT" and launched a wide range of initiatives that have helped the sector to develop.

Table 3. Examples of policy issues mentioned

"A lot of efforts are made by the "We have different interfaces to the government to diversify the economy, Government - we are not really there is a strong link as well between represented on the important European government and industry players due to Level etc....we only have a limited set of the small size of the country." Country experts but we do not use them efficiently director Gartner enough" Professor at German University

"The new government has a different "Luxembourg is still very flexible and approach and they seem to be more quick in creating the legal environment, willing to find solutions to improve perhaps we should have more resources Luxembourg's position". CEO Satellite to spot quickly enough the new Service Provider opportunities" Head of international sales incumbent operator

"We have good infrastructures, a legal and "Luxembourg is lacking a bit the in particular fiscal environment that is creativity - it is not enough to focus on favourable but we need to improve "Legal or regulatory" niches. 
constantly"

"Would E-archiving have been a good niche to enter into - well it took a lot of time to set up the legal environment and we still have nothing finalised"

"One of the strengths of Luxembourg was and still is to a certain extend its ability to adapt quickly and flexibly the EU regulations (e.g. tax rulings)" CIO global IT service provider

"We should develop our image as "Vision for ICT is there - there are some European Trusted Information Centre" good ideas - we need more courage, we Country manager global telco need more ambitions, a mindset change is equipment provider

"We are missing an overall strategic plan "We are flexible and small, access to although the government is shareholder in all 3 companies (RTL, SES, POST)" Representative of Business Federation needed" Serial entrepreneur in ICT

"We have invested a lot in Biotech - this is not a very good investment - there is no ecosystem and no industry that could take advantage of the research in this area" CEO satellite service provider politicians is easy, but what happens then?" CEO datacentre provider

Having said this, it was felt that more could have been done in terms of marketing and promotion of Luxembourg to the outside world and that the sector also needed a more coherent approach in terms of its representative bodies. Indeed, too many associations, forums, federations, clusters and agencies are claiming to represent their individual members' interests, but there is a lack of overall representation of the sector, both nationally as an interface to policy makers and internationally. In that respect, participants welcomed the recent creation of an overarching federation called ICT Luxembourg (Gaudron, 2014) as well as a new government strategic plan called Digital Lëtzebuerg (De Fooz, 2014b; Land, 2014) and expressed their hopes (and fears) that these initiatives might improve the situation.

Figure 7 (below) provides further details in terms of the policies initiatives that have been commented upon. Many participants, and in particular foreigners working and living in Luxembourg, identified its "smallness" as a major factor. This smallness leads to a high quality of life (low pollution, safety, nature, high standard of living) and, most importantly, to easy access to political decision makers implying the potential to react flexibly and quickly. On the other hand, many stakeholders also mentioned that this high standard of living also leads to high living costs and, consequently, high employment costs. In particular, housing has become extremely expensive making it difficult for young entrepreneurs to move to Luxembourg (Sorlut, 2014).

Several specific government initiatives were positively commented on. These included: the creation a specific status and certification for services providers to the financial sector (Deloitte, 2013), the focus on security, trust and data protection (Trân, 2013), initiatives around the usage and exploitation of big data (KMPG, 2014) and the legal framework on intellectual property rights (Raizer, 2014a). However, some people commented negatively on the fact the Luxembourg had still not managed to create a 
legal framework for "e-archiving"4 (Cencetti, 2014a; Ministère de 1'Economie et du Commerce Exterieur, 2013). Some participants also felt that more could have been achieved in terms of "e-government" (Gouvernement du Luxembourg, 2005) and "ehealth" (Henry, 2014a; PWC Luxembourg, 2013). It was also suggested that too much effort and money was spent on biotechnologies (Gouvernement du Luxembourg, 2013) as Luxembourg had experienced difficulties positioning itself in this competitive industry.

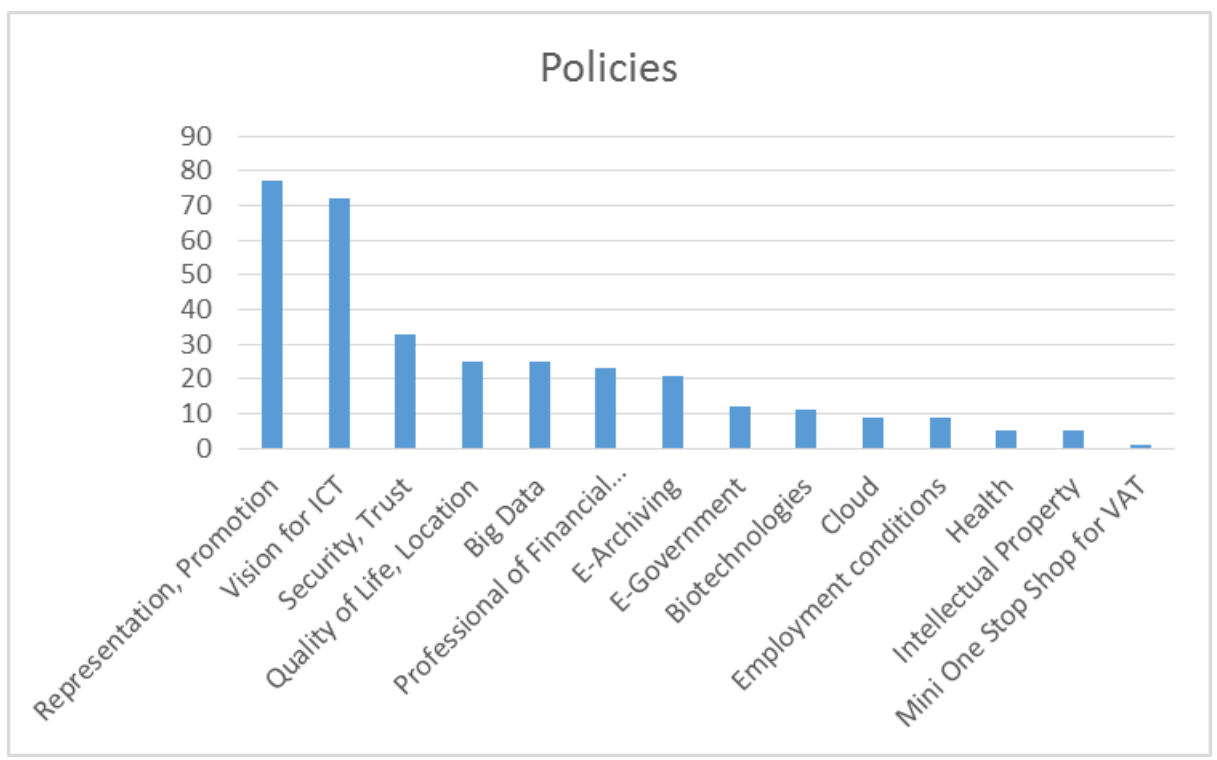

Figure 7 - Government policies identified according to number of mentions

Education and e-skills. The interviewees also insisted on the importance of relevant skills, both on a technical and scientific level but more generally the e-skills necessary to make the best use of ICT. It was found that Luxembourg has performed particularly badly on these "softer" elements. Participants actually complained about the fact that it became increasingly difficult to recruit the necessary employees on the local and even regional market, and that substantial effort was needed to attract such employees to Luxembourg. One or two interviewees identified missing e-skills as a major hindrance to their further growth and development. Several national studies are available to confirm this situation (Fedil, ABBL, \& CLC, 2014; Gouvernement du Luxembourg, 2011). However, this topic also appears to be a major issue in surrounding countries and generally in Europe (European Commission, 2014b; Gareis et al., 2014).

\footnotetext{
${ }^{4}$ The relevant law finally passed the parliament in July 2015 (Poujol, 2014b)
} 


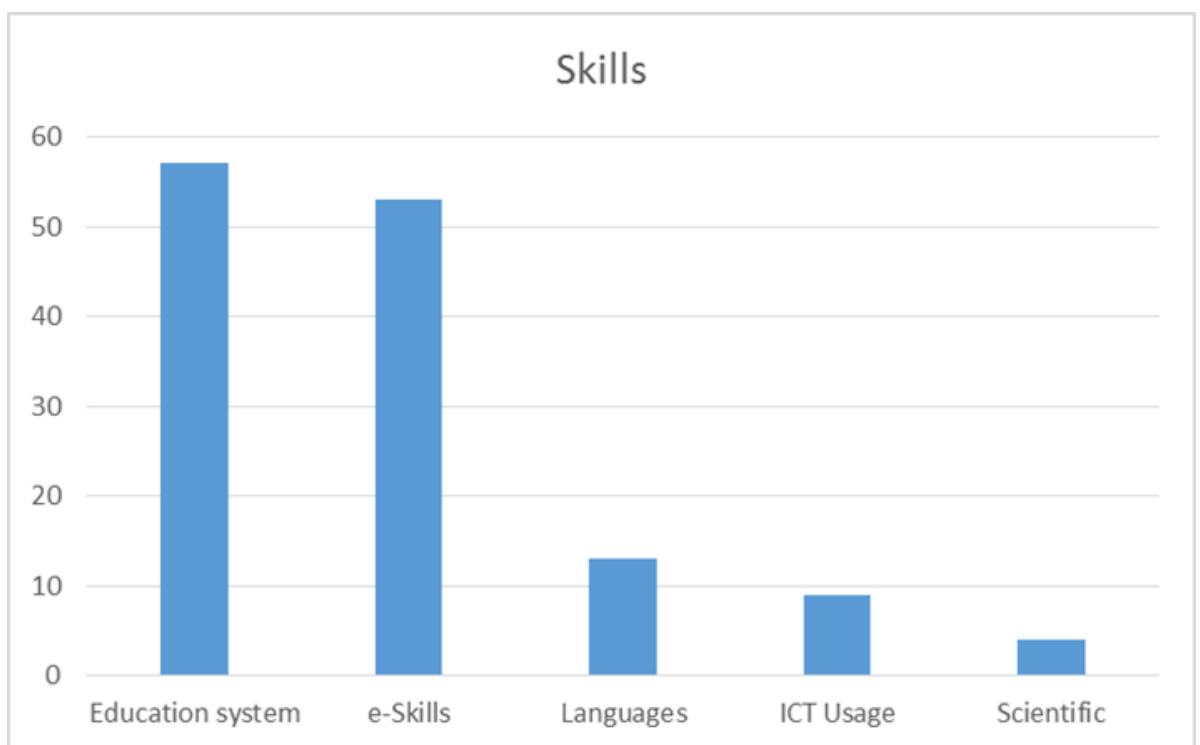

Fig. 8. Major issues related to education and skills according to number of mentions

Moreover, participants mentioned the lack of appropriate training and education within Luxembourg both in terms of software programming but also more generally in terms of technical and scientific education (European Schoolnet, 2012). Some also commented more broadly on the efficiency and effectiveness of Luxembourg's educational system, a system that is based on "tri-language" education and which needs some adaptations in the light of the quickly evolving social and technological environment (Gouvernment du Luxembourg, 2014a; OECD, 2014). Many of the participants highlighted the urgency of this issue and hoped that the government's new strategic plan would help to ease the situation (De Fooz, 2014c).

As an illustration of above, table 4 (below) provides a transcription of the statements made by some of the interviewees. This clearly shows that the topic is relevant at all level of the ecosystem and is also recognized by some of the education providers. Despite this apparent agreement, there is little agreement about what actually needs to be done and who should take this matter forward. Some participants argued for an initiative to be driven by the ecosystem actors themselves rather than by the different government ministries in charge. Independent from this discussion, all participants agreed that urgent action was needed as potential changes to the educational system could take several years before any noticeable effects emerge.

Table 4. Some of the main messages related to education and skills

"To develop the "digital business" we "We need to promote the fact that there
need first and foremost energy and are 6 universities around us and that we
cooling but in addition we have to be able have our own. But there is little
to attract young talents full of ideas and companies that are created by these
competencies. The difficulty of universities (seed-fund), there is no
Luxembourg is that it lacks attractiveness process, the professors are not motivated




\author{
for these people, they want to work hard to act in such a way" CEO Data Centre \\ and play hard, they want fun - we need to provider \\ be able to attract them" CEO Docler \\ Holding \\ "Parents are oriented their children into To find the right people - quickly, this is \\ non-technical jobs" Head of Sales the main issue" CTO ICT Integrator \\ Luxconnect \\ "We are not hiring any local people "The is no cooperation between the \\ anymore" COO Media Services educational system and industry" CEO \\ Provider ICT Integrator \\ "The Educational systems does not serve "our schools are not producing the right \\ ICT" University of Luxembourg \\ "English language should be more "Our education system is expensive but \\ developed - rather than being multi- not efficient, languages are still an \\ lingual we should be more international - advantage but there is an issue with \\ we tend to become regional focussing on English" CEO Data Centre provider \\ French, German and Luxembourgish, \\ Public school in English would increase \\ attractiveness tremendously" \\ "We have a problem recruiting Non-EU \\ staff, sometimes the process can take over \\ six months" Unit Manager University of \\ Luxembourg
}

Mind-set. Stimulating entrepreneurship and facilitating the creation of start-ups were also mentioned as important elements for the development of the ICT ecosystem.

It was found that Luxembourg lacks both the necessary processes and procedures but, more importantly, an entrepreneurial mind-set and this subject was mentioned more than a hundred times in different guises.

Participants also identified a general mind-set issue in terms of the risk awareness particularly of the local population. Indeed, a lot of young people prefer a job as a civil servant in an administration or local community to, a sometimes less well paid, job in the private sector. 


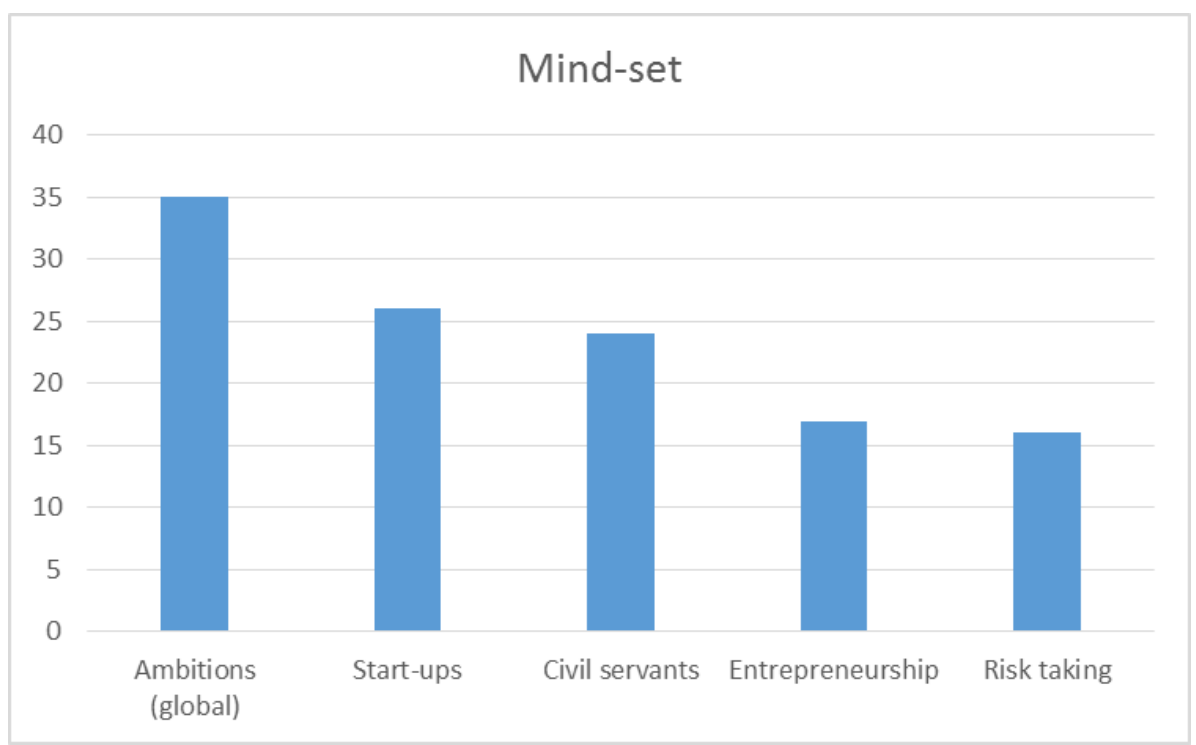

Fig. 9. Lack of entrepreneurial "spirit" according to number of citations

As for the education discussion detailed above, table 5 (below), provides examples of the comments collected during the interviews or collected from public statements. Again, all levels of the ecosystem are aware and somehow affected by this issue and it is interesting to note that even Luxembourg's prime minister is also aware of it.

Table 5. Some of the main messages related to "mind-set"

We are not ambitious enough - on an international scale we can do more. We have Luxembourg trade and investment offices in many places but we are not making best use of them. There is a lot of bright people but we are not using them. We are not clear what markets/customers to target? Where can we deliver an added value? CEO Network Equipment provider

"Luxembourg can only overcome its internal inertia with the help of foreigners but Government meetings tend to be closed to non-Luxembourgers because of language issues" Head of MVNE Alternative Mobile Operator

"We are focussing too much on ourselves and we believe to be better than we actually are. We should question ourselves more because otherwise after a while it might be too late"

"In Luxembourg unions are very strong and have major influence on political decisions" CIO IT Service provider for IKEA

"Major projects are driven by civil servants that do not want to make any mistakes rather than by managers that see the business value for Luxembourg" Member of management board of bankers association

"Risk taking culture and mind-set is "We want to stay what we are" Unknown literally in-existent" CEO Alternative - Luxembourgish saying Telecom Op.

"Luxembourgish people prefer a job as "if a start-up fails everybody looks down 
Innovation. Luxembourg's university, which is only 12 years old, was felt by many participants not yet to be fully aligned with the requirements of Luxembourg's economy (Paperjam, 2014a). It was also suggested that the same was true for the country's public research centers (Lambotte, 2014b). Technical, and in particular ICT education programs, are missing or very narrowly focused. There is also no business school attached to these programs (Luxemburger Wort, 2015).

There also have been only very limited creations of spin-offs or start-ups created through these institutions. It was felt that organizations facilitating these processes were not working efficiently (Cencetti, 2014b; Luxinnovation, 2013; Machuron, 2014) and that better coordination between them was needed. Many of the statements made have been recently confirmed in an OECD study about innovation policies in Luxembourg (OECD, 2015).

Luxembourg's financial center is well developed (Bourgain, Pieretti, \& Høj, 2009; Merker, 2013) and this may explain that access to finance was not generally found to be major issue (IT One, 2014). Access to initial, high risk, venture capital was identified as being of some importance but overall the main problems seems to be the lack of initiatives and ideas for new start-ups rather than their financing (Antzorn, 2014b; Lambotte, 2014a; Machuron, 2014)

Infrastructures. Developing ICT infrastructures has been confirmed as an important building block for a successful ICT ecosystem. Participants agreed that Luxembourg has been doing very well on these elements, with extensive high-quality, highresilience data center capacity (Service des Médias et des Communications, 2013), lowlatency international connectivity and broadband internet access are in place and used both by private individuals and professionals - see table 6 for examples of statements.

Table 6. Some of the main messages related to infrastructures

\begin{abstract}
"Perhaps we have focussed too long on infrastructures only. This is of course a very important element but an element only -without it we would not exist on the internet map" Global CIO of IT service provider for IKEA
\end{abstract}

"we focus too much on infrastructures, we are doing well in international rankings but the reality is a bit more nuanced".

"we have everything we need to create an international media hub (RTL, SES, POST), why are we not developing this?" Representative of Business Federation
"We have attractive electricity prices so far - this is a real advantage on an international scale. We do not produce electricity but we buy the cheapest and we have a small network leading to low transport charges" CEO Cloud service provider

"Logistics is also an issue, relatively poor flight connections, more and more traffic jams"

"Why have we spent that much money in T4 datacentres? This leads to a pressure to "sell-off" because the overcapacities are merely costing money. We have no clear strategy and positioning." Head of International Sales incumbent telecom 
"The broadband plan was created for the residential market - but this is again strengthening POST, as indeed the CATV networks are not associated to this development, this was only again an "alibi" plan to explain to the EU that we are following the rules as we should" Representative of alternative operators' association

"Datacentres - a very good initiative by the Government - Luxconnect is a real success, DRP sites are needed by all of the banks" Representative of bankers association
Infrastructures? Yes we are not experiencing any problem with this however there is too much focus on the Tier4 datacentre segment - we also need lower availability solutions - which are then cheaper CEO Security service provider

"...is there still a business for the pure international connectivity? is this not just a commodity, is this really a major differentiator?" CEO international datacentre provider

"Infrastructure is ok but Luxembourg risks to become a bit-pipe provider only. we have problems to deliver VAS" CEO of public Wifi network provider

These need to be supported, however, by investments in complementary infrastructures such as transportation (Antzorn, 2014a) and energy distribution networks (ILR, 2013b). Some participants made critical comments about unused capacity, both in terms of international communication links and data centers and mentioned the lack of space for larger data centers of a lower quality standard (Labro, 2015). Some also suggested that perhaps too much focus had been given to providing fiber connectivity to each household as part of the government's broadband strategy (SMC, 2010a). A more focused approach, making more use of the already existing CATV networks, might have been more effective (Henry, 2013; OPAL, 2013). 


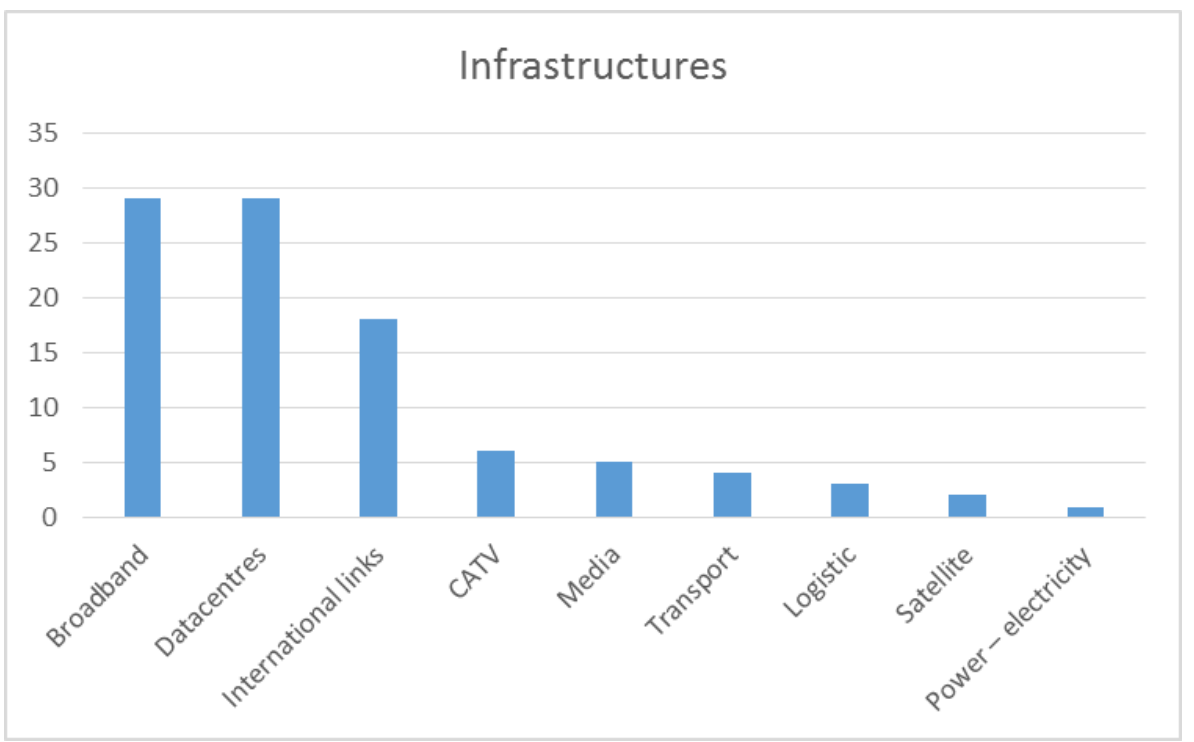

Fig. 10. Infrastructure related topics by number of citations

Participants were also asked how they saw the structure of the market following several years of liberalization and privatization efforts. It was felt by the participants to be very important to have an adequate mix of public and private investments, but that the incumbent operator after years of liberalization of the market was still very dominant. This could prevent both local investments as well as foreign direct investment par major ICT or telecommunications actors.

\section{Discussions and conclusions}

In this paper we have applied the layered model of Fransman to identify major industry participants within the different layers. An exploratory qualitative analysis building on interviews with over 50 participants in the ICT ecosystem in Luxembourg was undertaken.

Figure 11 (below) summarizes the main findings of the analysis. These have been derived using an inductive approach from the statements made by the interviewees. Interviewees have identified the different underlying internal and external forces. For some factors (green) the participants felt, to a large extend, that Luxembourg was performing well and that the ICT infrastructure as well the government's "vision for ICT" were considered to be particular strengths of Luxembourg. Educational topics, eskills and the missing "entrepreneurial mindset" were identified as major weaknesses. Growing international competition was identified as the main external threat that the ICT ecosystem is currently facing. 


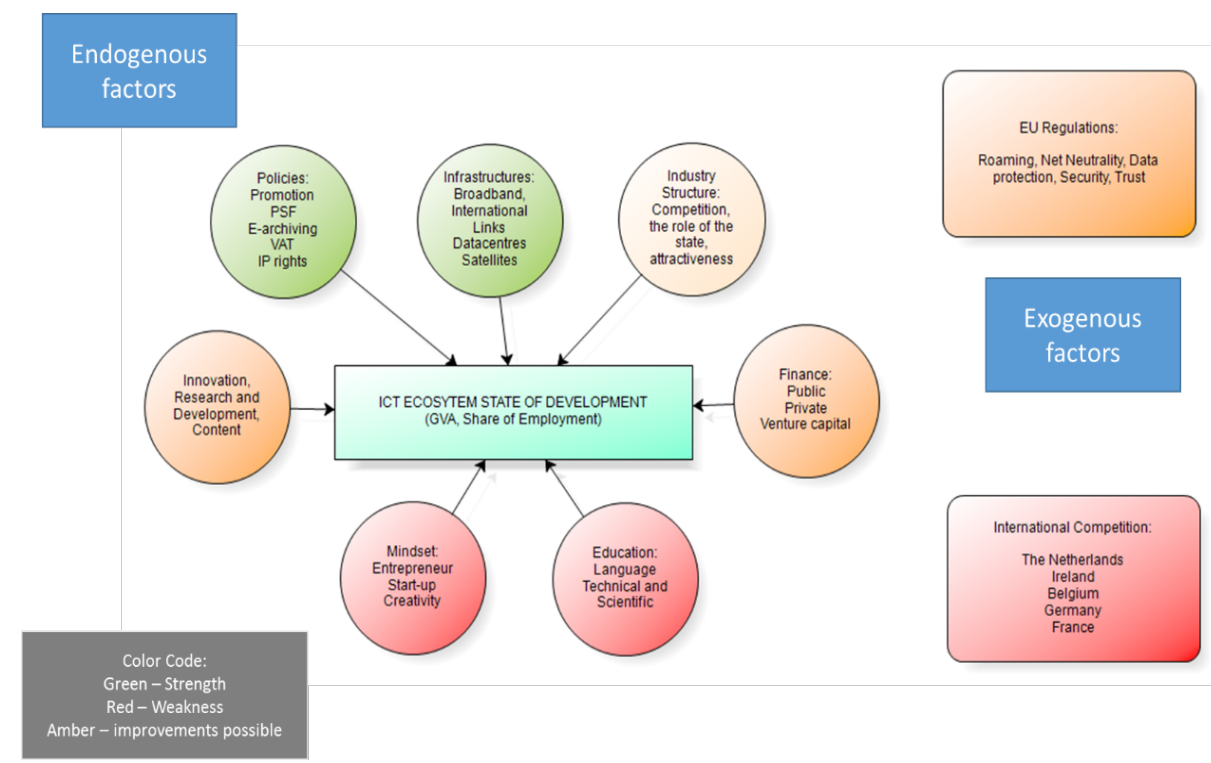

Fig 11. Summary overview of main forces affecting Luxembourg's ICT ecosystem

Participants confirmed that, according to them, Luxembourg has been successful in developing its ICT sector over the past 15 years, which is reinforced by international rankings and comparisons and 'official' reports. The government's initiatives have contributed to developing the underlying ICT infrastructures in terms of international connectivity, broadband and ultra-high broadband access as well as datacenter infrastructures. However, several participants also discussed the fact the success should not be defined and measured in terms of infrastructures alone and raised questions about the sustainability of this "kind of success". This was also confirmed by a recent public debate about the demand for datacenters (Labro, 2015) and uptake of broadband connectivity (Thiel, 2015).

Participants also confirmed that the industry structure has changed over time and that competition in several segments of the sector has increased. This competition has resulted in innovative products and services being offered at appropriate pricing levels, and these services have been adopted by both private users and enterprises. This, in turn, has led to the creation of jobs and added value for Luxembourg's economy. On the other hand, participants acknowledged that new challenges have appeared over time and that past policy initiatives may not be enough to sustain the sectors present set of competitive advantages. Clearly, Luxembourg is impacted by changes in EU rules and regulations which make it increasingly difficult to offer financial or tax advantages to companies investing in Luxembourg, and the government has faced some strong international pressures recently in that respect (Lecadre, 2014; Paperjam, 2014b; Raizer, 2014b, 2014c, 2014d). Consequently, it becomes more difficult to position Luxembourg successfully in the context of increased EU and even global competition and Luxembourg needs to make changes to its ICT ecosystem (Bervard, 2015). 
Innovation, entrepreneurship, the willingness to take risks and to start new ventures also appear to be underdeveloped. This issue was also confirmed by OECD (2015). Most importantly, participants felt that changes would be needed to innovation policies and $R \& D$ orientation of Luxembourg, as well as to the legal and regulatory environment to better facilitate or event stimulate the creation of start-ups. This was also confirmed by a previous study in which, Meyer (2008) discussed the difficulties to establish for example a "productive" R\&D environment in a small country like Luxembourg and concluded that it was very dependent on contributions from outside. There was also a wide consensus amongst participants that the strategy and vision of Luxembourg's university should be revisited and better adapted to the needs of local industry (Lalieu, 2015) and, in particular, its financial sector (Cencetti, 2015; Luxembourg for Finance, 2015).

Many factors could potentially contribute to the creation of 'unique selling points' for Luxembourg, but participants expressed concern that Luxembourg has been over reliant on developing its ICT infrastructures in terms national and international fiber connectivity and datacenters. Derived from interviews, we have also identified that Luxembourg has been unable, to date, to institutionalize an educational framework equipped to "produce" the necessary IT skills on a local basis due to a natural inertia in adapting the curriculums. Instead it has relied on importing knowledge from neighboring countries whilst focusing on its language skills and legal, financial and humanities education. In that respect the recent publication of the EU's digital economy and society index positioned Luxembourg in last position in the EU in terms students interested in technology, science and mathematics (Mateus, 2015). Different initiatives are now under discussion both on the supply side (new training programs, private schools, professional development) and on the demand side (promotion of Luxembourg as an attractive place to live and work) but all of these will take time to develop.

Finally, participants mentioned the relative lack of exploitation of the so-called "symbiotic relationships". One would expect that, due the small size of the country and the fact that access to political decision makers is quick and easy, ecosystem actors would be able to work closely together and establish both private and public-private partnerships and networks to develop the sector together as for example argued in Roolaht (2012). In practice, however, this is often not really the case as many of the larger actors are foreign and strategic decisions are taken outside of Luxembourg (Meyer, 2008). The government tries to improve this situation by, for example, the setting-up of several cluster initiatives (Federspiel et al., 2013) or the organization of common marketing and promotion activities in the context of economic missions (Luxembourg for Business, 2014).

\subsection{Managerial and policy implications}

Overall, the case of Luxembourg illustrates that it is important to examine the exogenous and endogenous dynamics of ICT ecosystems, which can reveal some nuances erased from international indices and high-level analyses, which could aide policymakers. The above analysis provides a first step and part of a wider effort to better understand the ICT ecosystem in Luxembourg, or in other small economies. The results are provisional as the research is on-going. Indeed, there is a need for deeper analysis of interview material for example by looking more deeply into the potentially 
different answers from actors within specific layers.

On the other hand, the conceptual framework presented in figure 11 can be applied in different settings and serve as a generic model to better identify and analyze the forces which shape for example ICT ecosystems within other small countries within the European Union.

\subsection{Limitations and avenues for further research}

The paper has benefitted from applying Fransman's model, which proved useful in identifying key stakeholders at different layers of the ICT ecosystem. It allowed the development of an overall summary diagram of the ecosystem (figure 3). It also allowed generating a representative sample of interview partners by strictly following the layer model.

The vast amount of qualitative data collected calls for a more in-depth analysis of the positions of actors within the different Fransman layers. Are there any similarities or differences in their respective views? Are some of the issues identified more important for actors of given layer? Are there any priorities that can be identified? A comparative analysis between the different layers might allow an even deeper understanding of the forces at play within Luxembourg's ICT ecosystem and the authors are currently developing their analysis further in that respect.

The Fransman model also had some limitations. It did not allow for example, the identification of all of the different subcategories that might have substantially different views and requirements within the different layers. Moreover, it is, by its very nature static and does not adequately cope with the dynamics of the ecosystem and recursive interrelationships that are manifold even during the short period covered by the study. Moreover, stakeholders can be - and are often -players in one, two or even more of the different layers and adopt a different position depending on the layer concerned. In addition, the model does not in itself give sufficient importance to external factors such as regulations or international competition. It does not, therefore, allow for the clear positioning of any supporting institutions and supporting agencies, such as for example, "Luxembourg for Business" or the different regulatory bodies as shown in figure 3.

These limitations notwithstanding, to the best of our knowledge, this is the first time that an in-depth analysis of Luxembourg's ICT ecosystem has been performed. This helps to redress the research imbalance, whereby small countries are often overlooked by scholars. Nevertheless, we contend that such "smallness" engenders a unique opportunity for research engagement with a majority of primary actors in ecosystems, which might be unfeasible in larger countries.

Comparative analysis, making use in particular of the conceptual framework in figure 11, of ICT ecosystems of small countries might be an interesting avenue of further research.

Furthermore, the general approach presented above, might also be transposed to other sectors or industries within Luxembourg and beyond. 


\section{$7 \quad$ References}

Anderson, C. (2010). Presenting and evaluating qualitative research. American Journal of Pharmaceutical Education, 74(8), 141. Retrieved from http://www.pubmedcentral.nih.gov/articlerender.fcgi?artid=2987281\&tool=pmc entrez\&rendertype $=$ abstract

Antzorn, F. (2014a, March 4). 31 heures de temps perdu dans les bouchons. Paperjam. Luxembourg.

Antzorn, F. (2014b, June 24). L' écosystème des start-up en à peine 300 clics. Paperjam. Luxembourg.

Arlandis, A., \& Ciriani, S. (2010). How Firms Interact and Perform in the ICT Ecosystem? Communications \& Strategies, 79(3), 121-141.

Basole, R. C., Park, H., \& Barnett, B. C. (2015). Coopetition and convergence in the ICT ecosystem. Telecommunications Policy, 39(7), 537-552.

Bazeley, P., \& Jackson, K. (2007). Qualitative Data Analysis with NVivo. Sage $\begin{array}{llll}\text { Publications (Vol. } & \text { 2nd). } & \text { Retrieved }\end{array}$ http://www.loc.gov/catdir/enhancements/fy0728/2006936346-d.html

Beekhuyzen, J. (2010). The Nvivo Looking Glass: Seeing the Data Through the Analysis. Qualitative Research, 1-12.

Bervard, L. (2015, May 9). Es gibt kein Wundermittel mehr. Luxemburger Wort, p. 24. Luxembourg.

Bettel, X. (2014, October 20). Xavier Bettel présente 1' initiative “ Digital Lëtzebuerg ." Gouvernement Du Luxembourg. Luxembourg.

Binsfeld, N., Whalley, J., \& Pugalis, L. (2013). Luxembourg - a bastion of stateownership in Europe. International Telecommunications Society Regional Conference. Brussels.

Binsfeld, N., Whalley, J., \& Pugalis, L. (2015). Competing against yourself: State duopoly in the Luxembourg telecommunications industry. Telecommunications Policy.

Bodson, L., \& Frising, A. (2015). Les TIC dans les ménages et chez les particuliers en 2014. Luxembourg.

Boston Consultancy Group. (2013). Reforming Europe's Telecoms Regulation to Enable the Digital Single Market. Brussels.

Bourgain, A., Pieretti, P., \& Høj, J. (2009). Can the Financial Sector continue to be the Main Growth Engine in Luxembourg? (No. 660). Paris. Retrieved from www.oecd.org

Briglauer, W. (2004). Generic reference model for the analysis of relevant communications markets: fundamental competition concepts. Info, 6(2), 93-104.

Cencetti, J. (2014a, July 21). L' archivage électronique, une nouvelle source économique. IT Nation. Luxembourg.

Cencetti, J. (2014b, September 24). Pour une meilleure coopération FNR et Luxinnovation. IT Nation. Luxembourg. 
Cencetti, J. (2015, February 27). Fintech in Luxembourg - Powering a Paradigm Shift. IT Nation. Luxembourg.

Cresswell, J. W. (2014). Research Design (4th ed.). London: Sage Publications.

Dard, D. (2013, July 20). L'ILR n'a pas chômée en 2012. Le Quotidien, p. 5. Luxembourg.

De Fooz, A. (2014a, October 6). La fin du roaming, vraiment? Soluxions, pp. 14-15. Luxembourg.

De Fooz, A. (2014b, October 21). Digital Lëtzbuerg, en avant! Soluxions. Luxembourg.

De Fooz, A. (2014c, October 22). "e-jobs", manque de "soft skills"! Soluxions. Luxembourg.

Deloitte. (2013, November 27). PSF en 2013 : panorama et perspectives d' un secteur en résilience. Paperjam. Luxembourg.

Easterby-Smith, M., Thorpe, R., \& Jackson, P. (2012). Management Research (4th ed.). London, UK: Sage Publications.

European Commission. (1987). Towards a dynamic European Economy Green Paper on the Development of the Common Market for Telecommunications Services and Equipment. Brussels. Retrieved from http://ec.europa.eu/greenpapers/pdf/green_paper_telecom_services__common_market_com_87_290.pdf

European Commission. (2010). A Digital Agenda for Europe. EU.

European Commission. (2013a). Digital Agenda Scoreboard 2013 Electronic communications market indicators : Definitions, methodology and footnotes on Member States. Brussels.

European Commission. (2013b). Digital Agenda Scoreboard key indicators. Retrieved from http://digital-agendadata.eu/datasets/digital_agenda_scoreboard_key_indicators/indicators

European Commission. (2013c). Measuring innovation output in Europe: towards a new indicator. Retrieved from http://ec.europa.eu/research/press/2013/pdf/indicator_of_innovation_output.pdf

European Commission. (2013d, September 11). Commission adopts regulatory proposals for a Connected Continent. Memo. Brussels.

European Commission. (2014a). Digital Agenda Scoreboard 2014 - Digital Performance of Luxembourg. Brussels.

European Commission. (2014b). e-SKILLS IN EUROPE Luxembourg Country report.

European Schoolnet. (2012). Survey of Schools: ICT in Education Country Profile Luxembourg.

Federspiel, L., Martin, G., Dentzer, T., Hengen, J.-P., Klesen, M., Meisch, F., \& Renotte, M. (2013, October 7). Luxembourg Cluster Initiative. IT Nation, pp. 129. Luxembourg. Retrieved from www.itnation.lu

Fedil, ABBL, \& CLC. (2014). Les TIC, ton job d'avenir! Edition 2014. Luxembourg. Retrieved from http://www.tic-tonjobdavenir.lu/brochure/

Fondation Idea. (2014, July 2). "Nation Branding" - nouveau positionnement du Luxembourg. Idée Du Mois 3, pp. 1-16. Luxembourg. 
Fransman, M. (2001). Evolution of the Telecommunications Industry into the Internet Age. Communications \& Strategies, (43), 57-113.

Fransman, M. (2002a). Mapping the evolving telecoms industry: the uses and shortcomings of the layer model. Telecommunications Policy, 26(9-10), 473483.

Fransman, M. (2002b). Telecoms and the internet age - from Boom to Bust to... (1st ed.). Oxford: Oxford University Press.

Fransman, M. (2004). The telecoms boom and bust 1996-2003 and the role of financial markets. Journal of Evolutionary Economics, 14(4), 369-406.

Fransman, M. (2006). Global Broadband Battles. (M. Fransman, Ed.) (1st ed.). Stanford: Stanford University Press.

Fransman, M. (2007). Innovation in the New ICT Ecosystem. International Journal of Digital Economics, (68).

Fransman, M. (2010a). The New ICT Ecosystem. The New ICT Ecosystem: Implications for Policy and Relation, (68).

Fransman, M. (2010b). The New ICT Ecosystem - Implications for Policy and Regulation (New and re.). Cambridge: Cambridge University Press. Retrieved from www.cambridge.org/9780521171205

Fransman, M. (2011). The evolving ICT industry in Asia and the implications for Europe. JRC Technical Notes, 63986, 78. Retrieved from http://ipts.jrc.ec.europa.eu/

Fransman, M. (2014). Models of Innovation in Global ICT Firms : The Emerging Global Innovation Ecosystems (No. EUR 26774 EN). (M. Bodganowicz, Ed.). Luxembourg: European Commission.

Garcia, A. S., \& Vicente, M. R. (2012). ICT Technologies in Europe : A Study of Technological Diffusion and Economic Growth under Network Theory (No. WPAD 2012.21).

Gareis, K., Hüsing, T., Birov, S., Budlova, I., Schulz, C., \& Korte, W. B. (2014). Eskills for jobs in Europe: Measuring progress and moving ahead.

Gaudron, J.-M. (2011, March 18). L' ILR change de tête. Paperjam. Luxembourg. Retrieved from www.paperjam.lu

Gaudron, J.-M. (2014, July 15). ICTluxembourg : «Une contrepartie homogène ». Paperjam. Luxembourg.

Gouvernement du Luxembourg. (2005). Plan directeur de la gouvernance électronique. Luxembourg.

Gouvernement du Luxembourg. (2011). Luxembourg e-skills 2011 repertory. Luxembourg: Gouvernement du Luxembourg.

Gouvernement du Luxembourg. (2013, October 10). Inauguration de LuxFold, société de biotechnologie, première start-up financée par le fonds Advent Life Science. Press Release. Luxembourg.

Gouvernement du Luxembourg. (2014, June 24). Francine Closener au sujet du “" Nation branding ." Gouvernement Du Luxembourg. Luxembourg. 
Gouvernment du Luxembourg. (2014a, February 10). Claude Meisch: “Dem Bildungskrich en Enn setzen ." Gouvernement Du Luxembourg.

Gouvernment du Luxembourg. (2014b, June 5). Lancement de la stratégie "Digital Lëtzebuerg" par le Conseil de gouvernement des 3 et 4 juin 2014. Gouvernement Du Luxembourg. Luxembourg.

Guardian, T. (2014, November 5). Luxembourg tax files: how tiny state rubberstamped tax avoidance on in industrial scale. The Guardian. London.

Hallikas, J., Varis, J., Sissonen, H., \& Virolainen, V. M. (2008). The evolution of the network structure in the ICT sector. International Journal of Production Economics, 115, 296-304.

Henry, R. (2013, November 28). L'OPAL mitigiée sur le déploiement du ultra-haut débit. IT Nation.

Henry, R. (2014a, March 25). L'adoption de services e-santé progresse trop lentement en Europe. IT Nation.

Henry, R. (2014b, April 3). Le Parlement européen met fin au roaming. IT Nation. Luxembourg.

ILR. (2013a, September 25). ILR: des litiges à resoudre en un clic. Paperjam. Luxembourg. Retrieved from www.paperjam.lu

ILR. (2013b, September 26). ILR: un comparateur du marché de l'électricité. Paperjam. Luxembourg. Retrieved from www.paperjam.lu

IT One. (2014, April 15). Luxembourg, un environnement propice pour les start-ups. IT One. Luxembourg.

Karagiannopoulos, G. D., Georgopoulos, N., \& Nikolopoulos, K. (2005). Fathoming Porter's five forces model in the internet era. Info, 7(6), 66-76.

Kim, H., Lee, J.-N., \& Han, J. (2010). The role of IT in business ecosystems. Communications of the ACM, 53(5), 151 .

King, N. (1998). Template analysis. In Qualitative methods and analysis in organizational research A practical guide (pp. 118-134).

Kitchell, M. (2010). Luxembourg as a Center for Online and ICT Business. Luxembourg. Retrieved from http://www.investinluxembourg.lu/ict/downloadfree-reports-page?sid=632

KMPG. (2014, January 31). If Big Data is the new gold, could Luxembourg be the perfect safe? KPMG Blog.

Koslowski, T. G., Longstaff, P. H., Vidal, M., \& Grob, T. (2012). Resilience Analysis of the ICT Ecosystem. In 23rd European Regional International Telecommunication Society conference; Vienna (pp. 1-18).

KPMG. (2013). Luxembourg Banks Insights 2013. Luxembourg. Retrieved from http://www.kpmg.com/LU/en/IssuesAndInsights/Articlespublications/Pages/Lux embourgBanks-Insights2013.aspx

Krylova, S. (2015). The ICT inventory in Luxembourg. Université du Luxembourg.

Labro, T. (2015, March 18). Les datacenters à l'épreuve. Luxemburger Wort, p. $1+12,13$. Luxembourg. 
Lalieu, J.-M. (2015). Débat pour une Uni 2.0. Paperjam, pp. 20-22. Luxembourg.

Lambotte, S. (2014a, April 8). Start-up: forces et faiblesses du Luxembourg. Paperjam. Luxembourg.

Lambotte, S. (2014b, December 18). En tête de LIST. Paperjam. Luxembourg.

Land. (2014, June 6). Digital Letzebuerg. Land, p. 9. Luxembourg.

Le Jeudi. (2015, May 14). Opal tance l'ILR. Le Jeudi, p. 20. Luxembourg.

Lecadre, R. (2014, December). Luxleaks: J'ai agi par conviction, la cohérence était d'assumer. Liberation. Paris.

Li, F., \& Whalley, J. (2002). Deconstruction Of The Telecommunications Industry: From Value Chains to Value Networks. Telecommunications Policy, 44(9-10), 451-472.

Lincoln, Y. S. (1995). Emerging Criteria for Quality in Qualitative and Interpretive Research. Qualitative Inquiry, 1(3).

Luxembourg for Business. (2013). LUXEMBOURG and ICT: a snapshot. Luxembourg. Retrieved from http://ict.investinluxembourg.lu/ict/luxembourgand-ict-a-snapshot

Luxembourg for Business. (2014, October). Luxembourg's ICT and E-commerce environment. Luxembourg for Business.

Luxembourg for Finance. (2015). FinTech in Luxembourg. Luxembourg for Finance Magazine. Luxembourg.

Luxemburger Wort. (2015, August 19). Luxembourg Chamber of Commerce plans business college. Wort. Luxembourg; Rennes.

Luxinnovation. (2013, October 16). Luxinnovation: plus qu'une nouvelle image. Paperjam. Luxembourg. Retrieved from www.paperjam.lu

Machuron, C.-L. (2014, March 6). Luxinnovation : la boutique des start-up. Silicon Luxembourg, pp. 1-6.

Maitland, C. F., Bauer, J. M., \& Westerveld, R. (2002). The European market for mobile data: evolving value chains and industry structures. Telecommunications Policy, 26(9-10), 485-504.

Mateus, A. (2015). DESI 2015 Digital Economy and Society Index Methodological note. Bruxelles.

Merker, J. (2013). A sectoral approach to the Luxembourg economy The financial sector. In Exploring the social. political and business environment of Luxembourg. Luxembourg: AMCHAM, Luxembourg School of Commerce.

Meyer, M. B. (2008). The dynamics of science in a small country: the case of Luxembourg. Science and Public Policy, 35(5), 361-371.

Ministère de l'Economie et du Commerce Exterieur. (2013, January 22). Archivage électronique: Étienne Schneider présente le projet de loi. Paperjam. Luxembourg. Retrieved from www.paperjam.lu

Neill, M. O. (2013). The NVivo Toolkit. Retrieved from http://explore.qsrinternational.com/nvivo-toolkit 
OECD. (2011). OECD Guide to Measuring the Information Society 2011. OECD Publishing.

OECD. (2014, September 9). Regards sur l'éducation 2014: le Luxembourg dans la comparaison internationale. Gouvernement Du Luxembourg. Luxembourg.

OECD. (2015). OECD Reviews of Innovation Policy Luxembourg 2015. Paris.

Oestreicher, K., Walton, N., \& Grove, H. (2012). New Internet-Based Technology Ecosystems. Worcester.

OPAL. (2013, November 28). Opérateurs alternatifs: «Ne nous oubliez pas!». Paperjam.

Paperjam. (2014a, June 10). Uni.lu: un déménagement sur fond de polémique. Paperjam. Luxembourg.

Paperjam. (2014b, November 6). LuxLeaks: le moment des ripostes. Paperjam. Luxembourg.

Partanen, J., \& Möller, K. (2011). How to build a strategic network: A practitioneroriented process model for the ICT sector. Industrial Marketing Management, In Press, 1-14.

Peppard, J., \& Rylander, A. (2006). From Value Chain to Value Network : Insights for Mobile Operators From Value Chain to Value Network: Insights for Mobile Operators. European Management Journal, 24(2).

Porter, M. E. (1990). Competitiveness: Challenging the Conventional Wisdom. Harvard Business Review, 68(3), 190-192.

Post Telecom. (2014, July 20). Cutting through EU VAT Complexity. Post Telecom Blog. Luxembourg.

Poujol, V. (2013, December 10). Concurrence : fusion ou rapprochement avec l'ILR ? Paperjam.

Poujol, V.(2014a, June 16). ILR : 5 mois d â€ $€^{\mathrm{TM}}$ attente puis plus de représentant privé. Paperjam. Luxembourg.

Poujol, V. (2014b, September 4). e-Archiving : une loi pour décembre au plus tard. Paperjam. Luxembourg.

PWC. (2011). Luxembourg: an e-hub for Europe Opportunities and actions on the horizon 2015. Luxembourg. Retrieved from http://www.pwc.lu/en/informationcommunication-technology/publications.jhtml

PWC Luxembourg. (2013, December 23). L'e-santé, bien plus qu'un projet informatique, un véritable enjeu de société. Communiqué de Presse. Luxembourg.

Quatraro, F. (2009). Martin Fransman: the new ICT ecosystem. Implications for Europe. Journal of Evolutionary Economics, 20(2), 321-328.

Rafique, K., Yuan, C., Tareen, A. W., Saeed, M., \& Hafeez, A. (2012). Emerging ICT Ecosystem - from Value Chain to Value Ecosystem. In 8th International Conference on Computing Technology and Information Management (ICCM), (pp. 95-100).

Raizer, T. (2014a, August 22). Propriété intellectuelle : l'union fera la force. Paperjam. Luxembourg. 
Raizer, T. (2014b, November 7). LuxLeaks: la deuxième lame du gouvernement. Paperjam. Luxembourg.

Raizer, T. (2014c, December 3). Corruption: Luxembourg progresse, avant LuxLeaks. Paperjam. Luxembourg.

Raizer, T. (2014d, December 14). LuxLeaks: l'inculpé s'explique. Paperjam. Luxembourg.

Roolaht, T. (2012). Innovation Systems in Small Catching-Up Economies. In Innovation Systems in Small Catching-up Economies: New Perspectives on Partice and Policy (pp. 21-38). New York: Springer.

Schultze, U., \& Avital, M. (2011). Designing interviews to generate rich data for information systems research. Information and Organization, 21(1), 1-16.

Service des Médias et des Communications. (2013). Luxembourg \& ICT - a snapshot. Luxembourg. Retrieved from http://ict.investinluxembourg.lu/ict/luxembourgand-ict-a-snapshot

SMC. (2010a). Stratégie nationale pour les réseaux à «ultra-haut» débit. Luxembourg. $\quad$ Retrieved from http://www.mediacom.public.lu/institutions/Institutions_nationales/smc/201003 09_ngn/Strategie_nationale_pour_les_reseaux_a_ultra-haut_debit.pdf accessed 15 th of January 2013

SMC. (2010b). Why Luxembourg? A Comprehensive Overview of the Regulatory, Economic and Lifestyle Advantges for ICT and Media Companies. Luxembourg. Retrieved from http://www.investinluxembourg.lu/ict/download-free-reportspage? sid $=632$

Sorlut, P. (2014, January 23). «Les coûts, le défi au Luxembourg». Paperjam.

STATEC. (2013). Luxembourg Figures 2013. Retrieved from http://www.statistiques.public.lu/catalogue-publications/luxembourg-enchiffres/luxembourg-figures.pdf

Thelen, C. (2012, December). PIB: interpréter les données avec prudence. Paperjam. Retrieved from www.paperjam.lu

Thiel, M. (2015). Das Glasfasergrossherzogtum. Wort, p. 22. Luxembourg.

Trân, A. (2013, June 10). Security as an infrastructure. IT Nation. Luxembourg. Retrieved from www.itnation.lu

Veugelers, R. (2012). New ICT sectors: Platforms for European Growth?

Welsh, E. (2002). Dealing with Data: Using NVivo in the Qualitative Data Analysis Process. Forum Qualitative Sozialforschung / Forum: Qualitative Social Research, 3. Retrieved from http:/www.qualitativeresearch.net/index.php/fqs/article/view/865/1880

Wong, L. P., Medicine, F., \& Lumpur, K. (2008). Data Analysis in Qualitative Research: A Brief Guide to Using NVivo. Malaysian Family Physician, 3, 14-20.

World Economic Forum, Dutta, S., Geiger, T., \& Lanvin, B. (2015). The Global Information Technology Report 2015. (S. Dutta, T. Geiger, \& B. Lanvin, Eds.). Geneva. Retrieved from www.weforum.org/gitr 
Yin, R. K. (2009). Case Study Research: Design and Methods. (L. Bickman \& D. J. Rog, Eds.) Essential guide to qualitative methods in organizational research (Vol. 5). London: Sage Publications. 